\title{
A model for network design of supply chain management in research projects
}

\author{
Mohammad Forozandeh $^{\text {a }}$, Ebrahim Teimoury ${ }^{a^{*}}$ and Ahmad Makui ${ }^{\mathrm{a}}$
}

${ }^{a}$ Department of Industrial Engineering, Iran University of Science and Technology, Tehran, Iran

\begin{tabular}{l}
\hline C H R O N I C L E \\
\hline Article history: \\
Received March18, 2017 \\
Accepted November 202017 \\
Available online \\
December 162017 \\
\hline Keywords: \\
Project supply chain management \\
Research projects \\
Network design
\end{tabular}

\section{Introduction}

Presently, many project based organizations need to integrate research and production with supply as three-dimensional concurrent engineering to solve their problems (Yeo \& Ning, 2002). One of the tools used in this area is the new concept of project supply chain management (PSCM), which was first introduced by Asbjørnslett in 1980 and less discussed thereafter (Asbjørnslett, 2003). Many projectbased organizations show resistance towards accepting and using supply chain techniques and strategies as this type of organization was dropped in the engineering and the construction industry due to low product quality, low profit margins, high time, and costs (Basu, 2011; Tarziján \& Brahm, 2014). It was estimated that about $40 \%$ of the work in the construction industry includes non-value added activities such as time spent waiting for approvals or in receiving materials at the project site (Mohamed \& Tucker, 1996). Research project supply chains have two strategies in the Iranian industries: the pull strategy in response to the market and the push strategy in response to technological pressure. In the pull strategy, project-driven organizations have faced great problems in the integration levels and actions in the acquisition cycle, supply, and support in the life cycle, in which they are facing serious challenges (Ghassemi et al., 2018).

* Corresponding author

E-mail address: teimoury@iust.ac.ir (E. Teimoury)

(C) 2018 by the authors; licensee Growing Science, Canada doi: $10.5267 /$ j.uscm.2017.12.004 
In the push strategy, research projects have faced rapid technological changes. If they cannot be flexible and adapt to environmental conditions, projects will not be efficient and will not be effective in the operating environment. It should, therefore, be possible to reduce the gap between idea creation and production output (the project lifecycle) in the shortest possible time with the optimization and integration levels, and the layers involved and infrastructure. So, the main purpose of this paper is to do a network design of supply chain management for research projects and to elaborate a quantitative method for the stakeholders' selection process. In addition, the developed model takes multiple objectives into account, and more specifically is based on the goal programming approach. The mathematical model will imply to indicate the best basket of partners to collaborate in the Research projects. Finally to illustrate the applications of the model, experiment hypothetical but realistic data of Iranian organization is used in a research project. The model is implemented in the GAMS Optimization software.

This article is structured as follows: first, a theoretical background and literature review on project supply chain management in research projects are presented and summarized; second, the modelling assumptions are discussed and the expected cost functions are calculated; the numerical results and the parametric analysis are thereafter presented; and finally, our findings are summarized.

\section{Theoretical background and literature review}

Research projects are temporary set of activities with clear goals, limited time and resource, and high uncertainties to fulfil scientific discovery and production of new knowledge or to achieve certain system tools, to meet the expectations of the business environment (product or services) and includes any scientific research in science, technology and systems at any level of the organizational levels (Wingate, 2014; Lock, 1994).

Supply chain management (SCM) is a set of approaches utilized to efficiently integrate suppliers, manufacturers, warehouses and stores, so that merchandise is produced and distributed at the right quantities, to the right locations, and at the right time, in order to minimize system-wide costs while satisfying service level requirements (Chopra \& Meindl, 2007; Beamon, 1998). Traditional managers concentrated only on their own firms. They treated supplier and customer as competitive firms. They never considered the potential for one another to cooperate as partners. In many cases, they dealt with each other very competitively, fearing to lose advantages by customers or suppliers. As a result, in the 1980s and 1990s more companies continued to integrate (Beamon, 1998). Recently there has been an increasing interest in the performance, design, and study of the supply chain as a whole. Mangan and Lalwani (2016) illustrated the evolution and structure of the integrated supply chain (Fig. 1).

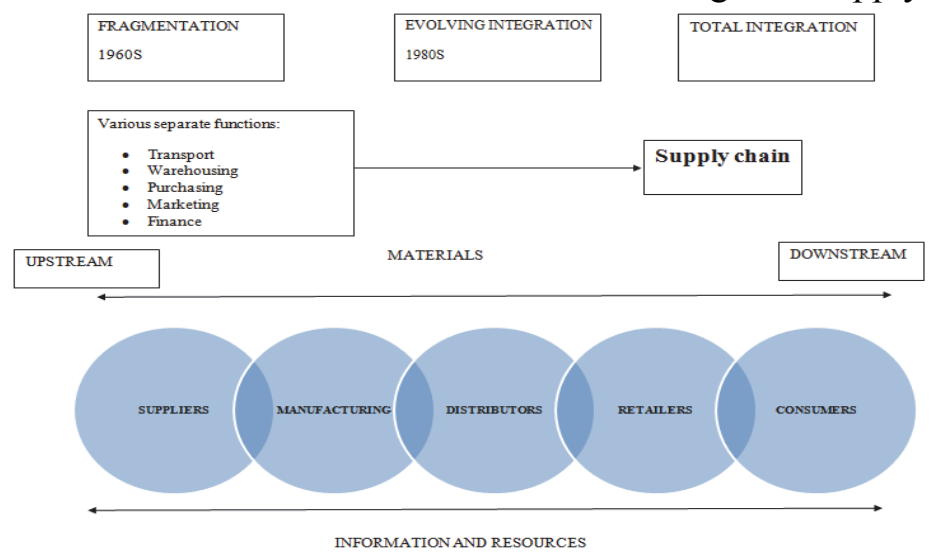

Fig. 1. The integrated supply chain (Source: Mangan \& Lalwani, 2016)

According to the Council of Supply Chain Management Professionals (2010), the "Supply Chain Management" can be defined as: "Supply Chain Management encompasses the planning and management of all activities involved in sourcing and procurement, conversion, and all logistics 
management activities". Importantly, it also includes coordination and collaboration with channel partners, which can be suppliers, intermediaries, third-party service providers, and customers (Morris \& Pinto, 2010). In essence, supply chain management integrates supply and demand management within and across companies (Vollmann et al., 1995). The central theme of all definitions is the integration of all entities and functions to convert raw materials to finished goods or service throughout a supply chain by adding value to deliver to the customer. It is obvious that the management of this integrated network requires extensive efforts (Tam et al., 2011; Crine, 1998).

Project Supply chain management has emerged both from the supply chain and the project management domain. Many of researches are related to functional elements of supply chain and materials management, project planning and control perspective but do not outline the project supply chain management concept (Basu, 2011). Project supply chain management in research projects has received less attention in recent years (Wingate, 2014; Mishra, et al., 2015). In fact project Supply Chain Management is the management of a complex and dynamic network of integrated companies, organizations and stakeholders which are involved in different chains for satisfying the project final customer (Nassimbeni, 1998). Project supply chain management seeks value enhancement in projects through logistics' focus on demand and supply alignment. This is met through the characteristics of logistics throughout the project life cycle to demand chain management in the development phase and to supply chain management in the operations phase (Basu, 2011; Asbjørnslett, 2003). So, project supply chain management, includes interact and communicate with a wide range of external actors such as operators, suppliers, subcontractors and main contractors for collaboration and cooperation (Parrod et al., 2007; Siniharju, 2000; Schultze \& Unruh., 1996; Min, 2001). Fundamental mechanisms for access to external knowledge of organization include a variety of methods such as competition, strategic alliances, joint ventures, grant and licensing, open source platforms and creating a joint product (Beamon, 1998; Goetschalckx et al., 2002). The success of the research cycle is associated with control and integrity of supply, production and design. Therefore, project-organizations must be seen the design and production process together and in early phases of project life and the feasibility study phase, development and production, supply and distribution, maintenance and services after sale and push technology (Cousins \& Spekman, 2003; Eriksson, 2015).

Literature shows that supply chain management in project or in part of project management is not clear even though it does not examine in knowledge area of project management institute and in project management standards. However, many experts and authors have mentioned its importance in project management area. Project supply chain management has been addressed by several authors approaching the topic from different views, and with different objectives (Table 1).

\section{Table 1}

Different area of topic

\begin{tabular}{ll}
\hline Topic & Authors \\
\hline Supply chain management in the oil \& gas industry & Silver 1986, CRINE 1998, Burton et al. 1999 \\
Materials management in construction projects & Kerridge 1987 \\
Materials management as part of project management & Harrison \& Lock, 2004 \\
Partnering and alliances in the oil and gas industry & Schultzel \& Unruh, 1996; Vollmann et al. 1995 \\
Project-oriented supply chain management & Asbjørnslett, 2003 \\
\hline
\end{tabular}

In the research project supply chain, there are many entities including client, main contractor, subcontractors, main executer, suppliers and supervisor \& consulter with some links between them (Fig. $2)$. We have different selections in life cycle of research projects for example: project selection, contractor and sub-contractor selection, supplier selection, executer selection, and alternatives selection. These links represent the flow of materials, services, cash, and information that it make possible the functions of exploration, design, production, utilization and disposal. Consequently, it is apparent that the modeling approach and solution methods are very closely associated with the 
complexity of the supply chain structure. In addition, within developing solution techniques and enhancing of the capability of modern computing technologies over the last years, researchers have dealt with more complicated project supply chain structures (Wingate, 2014; Cousins \& Spekman, 2003; Beamon, 1998). In this paper due to complexity of research project, network structure is choice.

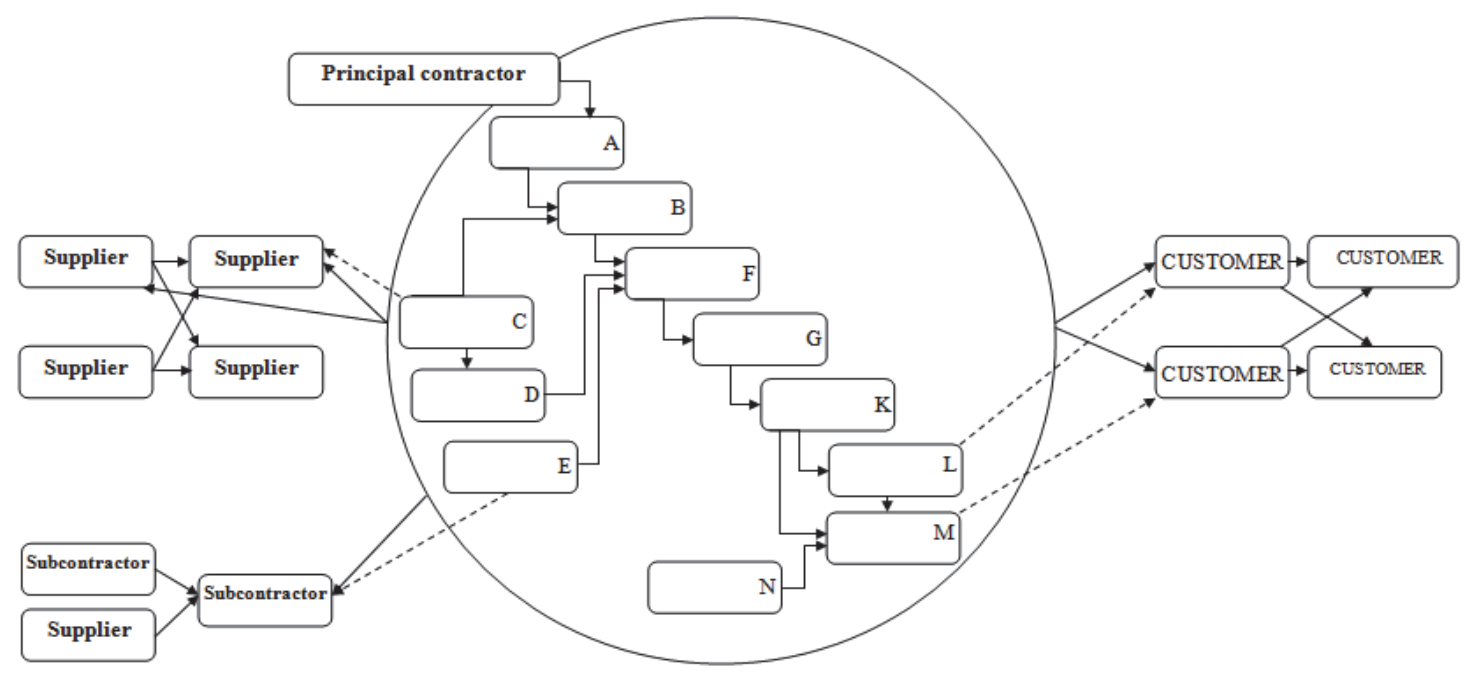

Fig. 2. The project supply chain

As mentioned previously, one of the key criteria of our selection process was the integration and expansion of the model for whole life cycle of projects. The life cycle of the research project commences with the statement of a need and it ends with the disposal of the project. There is no universally accepted agreement on how many phases exist in a project life cycle. In this article, the project life cycle is defined by Blanchard and Fabrycky, and MIL-STD 499B according Fig. 3. The life cycle of research projects can be divided into five main stages: need assessment, feasibility study, conceptual design, preliminary design and detail design (Turner, 2008).

Fig. 3. Research project life cycle (Source: Turner, 2008)

Therefore, we need integrated model in better management of them for optimization of time and cost. In fact, choosing the stakeholders and their allocation is a complicated optimization problem.

\section{Research methodology}

This study proposes a mathematical model to determine the optimal combination of the main contractors, executers, and the various alternatives for project implementation and how the devolution of activities in each of the five stages of the project are divided among consultants for monitoring, suppliers for the supply of materials, specialized labor, and product. The model's aims are to minimize the cost of the project and minimize the project time required for implementation of the project. The methodology for solving the network problem is developed by the means of a five-step procedure. Fig. 4 indicates the steps of this methodology. 


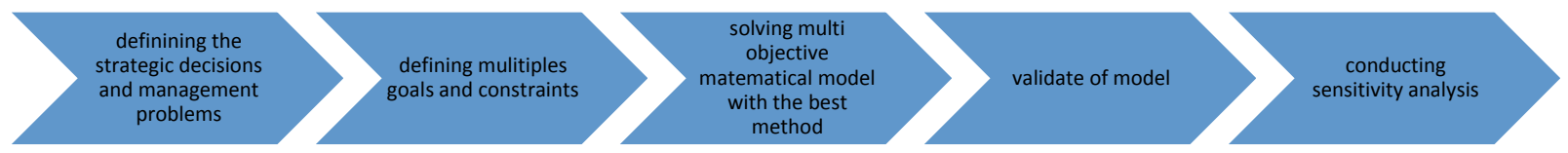

Fig. 4. The Proposed methodology

The assumptions of the model are:

- All the objectives and constraints are considered linear functions.

- The earliest start time of the project is equal to $0(\mathrm{E} 1=0)$.

- A project with $N$ activities is considered. The precedence relations of the activities are zerolag, finish to start; it is shown by an activity on the node network with no loop. Activities 1 and $N$ are dummies that represent the project start and project completion, respectively.

- All the research projects are conducted in five stages including feasibility study and conceptual design, preliminary design, detail design, construction and production, and utilization.

- The amount required from material $m$ to process activity $j$ is independent from the activity duration.

- All the amounts of each material needed for each activity are ordered at the same time.

- To carry out any project, one must first select a main contractor.

- The main contractor works with a project executor. So, the main contractor selection is the decision variable of the model.

- The selected executer should select and execute an option among the available alternatives to implement the project in order to achieve the ultimate goals such as the optimization of objective functions.

- After the selection of the existing alternatives, the beginning of the project life cycle includes the conceptual design stage, the preliminary design stage, the detailed design phase, the production phase, and the utilization phase.

- Each of the above steps consists of activities that need a series of suppliers and a consultant to supervise their implementations. There are many suppliers and consultants for each activity for selection that our decision variables in this model are a fraction of the supply and the monitoring of any activity that is included in any of the available options.

The signs and symbols (indices, parameters, and decision variables) in the entire text of the article are used in order to explain the problem areas, assumptions and mathematical modelling. In Table 2, the symptoms related to the used indices in the problem modelling are given.

\section{Table 2}

The indices that are used in the model

\begin{tabular}{ll}
\hline Indices & Description \\
\hline$i_{1}=1, \ldots, n_{1}$ & The index for the selection of the main contractor \\
$i_{2}=1, \ldots, n_{2}$ & The index for the selection of the project executer \\
$i_{3}=1, \ldots, n_{3}$ & The index for the selection of alternatives \\
$i_{4}=1, \ldots, n_{4}$ & The index for activities of conceptual design \\
$i_{5}=1, \ldots, n_{5}$ & The index for activities of preliminary design \\
$i_{6}=1, \ldots, n_{6}$ & The index for activities of detail design \\
$j_{1}=1, \ldots, m_{1}$ & The index for the suppliers of conceptual design activities \\
$j_{2}=1, \ldots, m_{2}$ & The index for the consulters of conceptual design activities \\
$j_{3}=1, \ldots, m_{3}$ & The index for suppliers of preliminary design activities \\
$j_{4}=1, \ldots, m_{4}$ & The index for consulters of preliminary design activities \\
$j_{5}=1, \ldots, m_{5}$ & The index for suppliers of detail design activities \\
$j_{6}=1, \ldots, m_{6}$ & The index for consulters of detail design activities \\
\hline
\end{tabular}


In Table 3, the symptoms related to the used parameters in the modelling are shown:

Table 3

Used parameters in the model

\begin{tabular}{|c|c|}
\hline Parameter & Description \\
\hline Demand $_{i_{1}, i_{2}, i_{3}, i_{4}}$ & The demand or requirements related to the $i_{4}$ activity in the conceptual design \\
\hline CapSupe $_{i_{1}, i_{2}, i_{3}, i_{4}, j_{1}}$ & The response capacity of $j_{1}$ suppliers to the $i_{4}$ activity in the conceptual design phase \\
\hline $\operatorname{lag}_{i_{1}, i_{2}, i_{3}, i_{4}, i_{4}^{\prime}}^{\prime}$ & $\begin{array}{l}\text { The time distance between the end of the } i_{4} \text { activity and start of the } i_{4}^{\prime} \text { activity in the conceptual } \\
\text { design phase }\end{array}$ \\
\hline $\operatorname{tesup}_{i_{1}, i_{2}, i_{3}, i_{4}, i_{5}, j_{3}}$ & $\begin{array}{l}\text { The required time for doing of the } i_{4} \text { activity if it is fully transferred to the } j_{1} \text { supplier in the } \\
\text { conceptual design phase }\end{array}$ \\
\hline Demand $c_{i_{1}, i_{2}, i_{3}, i_{4}}$ & Demand or counselling need or the monitoring of the $i_{4}$ activity in the conceptual design phase \\
\hline CapConse $_{i_{1}, i_{2}, i_{3}, i_{4}, j_{2}}$ & The response capacity of the $j_{2}$ consultant to the $i_{4}$ activity in the conceptual design phase \\
\hline $\operatorname{csupe}_{i_{1}, i_{2}, i_{3}, i_{4}, j_{1}}$ & $\begin{array}{l}\text { The required cost to perform the } i_{4} \text { activity if it is fully transferred to the } j_{1} \text { supplier in the conceptual } \\
\text { design phase }\end{array}$ \\
\hline cconse $_{i_{1}, i_{2}, i_{3}, i_{4}, j_{2}}$ & $\begin{array}{l}\text { The required cost to perform the } i_{4} \text { activity if it is fully transferred to the } j_{2} \text { consultant in the } \\
\text { conceptual design phase }\end{array}$ \\
\hline $\operatorname{Demand}_{i_{1}, i_{2}, i_{3}, i_{5}}$ & The demand or requirements related to the $i_{5}$ activity in the preliminary design \\
\hline $\operatorname{CapSupc}_{i_{1}, i_{2}, i_{3}, i_{5}, j_{3}}$ & The response capacity of $j_{3}$ suppliers to the $i_{5}$ activity in the preliminary design phase \\
\hline $\operatorname{lag}_{i_{1}, i_{2}, i_{3}, i_{5}, i_{5}^{\prime}}$ & $\begin{array}{l}\text { The Time distance between the end of the } i_{5} \text { activity and start of the } i_{5}^{\prime} \text { activity in the preliminary } \\
\text { design phase }\end{array}$ \\
\hline $\operatorname{tcsup}_{i_{1}, i_{2}, i_{3}, i_{5}, j_{3}}$ & $\begin{array}{l}\text { The required time for doing of the } i_{5} \text { activity if it is fully transferred to the } j_{3} \text { supplier in the } \\
\text { preliminary design phase }\end{array}$ \\
\hline Demand $c_{i_{1}, i_{2}, i_{3}, i_{5}}$ & Demand or counselling need or the monitoring of the $i_{5}$ activity in the preliminary design phase \\
\hline $\operatorname{CapConsc}_{i_{1}, i_{2}, i_{3}, i_{4}, j_{4}}$ & The response capacity of the $j_{4}$ consultant to the $i_{5}$ activity in the preliminary design phase \\
\hline $\operatorname{csupc}_{i_{1}, i_{2}, i_{3}, i_{5}, j_{3}}$ & $\begin{array}{l}\text { The required cost to perform the } i_{5} \text { activity if it is fully transferred to the } j_{3} \text { supplier in the } \\
\text { preliminary design phase }\end{array}$ \\
\hline $\operatorname{cconsc}_{i_{1}, i_{2}, i_{3}, i_{5}, j_{4}}$ & $\begin{array}{l}\text { The required cost to perform the } i_{5} \text { activity if it is fully transferred to the } j_{4} \text { consultant in the } \\
\text { preliminary design phase }\end{array}$ \\
\hline Demand $_{i_{1}, i_{2}, i_{3}, i_{6}}$ & The demand or requirements related to the $i_{6}$ activity in the detail design \\
\hline CapSupd $_{i_{1}, i_{2}, i_{3}, i_{6}, j_{5}}$ & The response capacity of $j_{5}$ suppliers to the $i_{6}$ activity in the detail design phase \\
\hline $\operatorname{lag}_{i_{1}, i_{2}, i_{3}, i_{6}, i_{6}^{\prime}}$ & $\begin{array}{l}\text { The Time distance between the end of the } i_{6} \text { activity and start of the } i_{6}^{\prime} \text { activity in the detail design } \\
\text { phase }\end{array}$ \\
\hline $\operatorname{tdsup}_{i_{1}, i_{2}, i_{3}, i_{6}, j_{5}}$ & $\begin{array}{l}\text { The required time for doing of the } i_{6} \text { activity if it is fully transferred to the } j_{5} \text { supplier in the detail } \\
\text { design phase }\end{array}$ \\
\hline Demandc $c_{i_{1}, i_{2}, i_{3}, i_{6}}$ & Demand or counselling need or the monitoring of the $i_{6}$ activity in the detail design phase \\
\hline $\operatorname{CapConsd}_{i_{1}, i_{2}, i_{3}, i_{6}, j_{6}}$ & The response capacity of the $j_{6}$ consultant to the $i_{6}$ activity in the detail design phase \\
\hline $\operatorname{csupd}_{i_{1}, i_{2}, i_{3}, i_{6}, j_{5}}$ & $\begin{array}{l}\text { The required cost to perform the } i_{6} \text { activity if it is fully transferred to the } j_{5} \text { supplier in the detail } \\
\text { design phase }\end{array}$ \\
\hline $\operatorname{cconsd}_{i_{1}, i_{2}, i_{3}, i_{6}, j_{6}}$ & $\begin{array}{l}\text { The required cost to perform the } i_{6} \text { activity if it is fully transferred to the } j_{6} \text { consultant in the detail } \\
\text { design phase }\end{array}$ \\
\hline
\end{tabular}

In Table 4, the symptoms related to decision variables and their dependent variables are shown.

\section{Table 4}

Decision variables

\begin{tabular}{|c|c|}
\hline Variable & Description \\
\hline$M C_{i_{1}}$ & Variable related to the selection or not to the selection of the main contractor \\
\hline$E X_{i_{1}, i_{2}}$ & Variable related to the selection or not to the selection of the project executer \\
\hline$A_{i_{1}, i_{2}, i_{3}}$ & Variable related to the selection or not to the selection of alternatives \\
\hline $\operatorname{supe}_{i_{1}, i_{2}, i_{3}, i_{4}, j_{1}}$ & Variable related to a fraction of the $i_{4}$ activity supply of the $j_{1}$ suppliers in the conceptual design phase \\
\hline $\operatorname{tes}_{i_{1}, i_{2}, i_{3}, i_{4}}$ & Start time of $i_{4}$ activity in the conceptual design phase \\
\hline$t e f_{i_{1}, i_{2}, i_{3}, i_{4}}$ & Completion time of $i_{4}$ activity in the conceptual design phase \\
\hline$t e_{i_{1}, i_{2}, i_{3}, i_{4}}$ & The required time for implementation of $i_{4}$ activitiy in the conceptual design phase \\
\hline$T E D$ & The finish time of the conceptual design phase \\
\hline conse $_{i_{1}, i_{2}, i_{3}, i_{4}, j_{2}}$ & Variable related to a fraction of the $i_{4}$ activity supply of the $i_{2}$ counsellor in the conceptual design phase \\
\hline$C E D$ & The total cost of conceptual design phase \\
\hline $\operatorname{supc}_{i_{1}, i_{2}, i_{3}, i_{5}, j_{3}}$ & Variable related to a fraction of $i_{5}$ activity supply from $j_{3}$ suppliers in the preliminary design phase \\
\hline$t c s_{i_{1}, i_{2}, i_{3}, i_{5}}$ & Start time of $i_{5}$ activity in the preliminary design phase \\
\hline$t c f_{i_{1}, i_{2}, i_{3}, i_{5}}$ & Completion time of $i_{5}$ activity in the preliminary design phase \\
\hline
\end{tabular}




\begin{tabular}{ll}
\hline$t c_{i_{1}, i_{2}, i_{3}, i_{5}}$ & The required time for implementation of $i_{5}$ activitiy in the preliminary design phase \\
$T C D$ & Finish time of preliminary design phase \\
$\operatorname{consc}_{i_{1}, i_{2}, i_{3}, i_{5}, j_{4}}$ & variable related to fraction of the $i_{5}$ activities supply of $j_{4}$ counselor in the preliminary design phase \\
$C C D$ & Total cost of preliminary design phase \\
$\operatorname{supd} d_{i_{1}, i_{2}, i_{3}, i_{6}, j_{5}}$ & Variable related to a fraction of $i_{6}$ activity supply from $j_{5}$ suppliers in the detail design phase \\
$t d s_{i_{1}, i_{2}, i_{3}, i_{6}}$ & Start time of $i_{6}$ activity in the detail design phase \\
$t d f_{i_{1}, i_{2}, i_{3}, i_{6}}$ & Completion time of $i_{6}$ activity in the detail design phase \\
$t d_{i_{1}, i_{2}, i_{3}, i_{6}}$ & The required time for implementation of $i_{6}$ activitiy in the detail design phase \\
$T D D$ & Finish time of detail design phase \\
$\operatorname{cons} d_{i_{1}, i_{2}, i_{3}, i_{6}, j_{6}}$ & variable related to fraction of the $i_{6}$ activities supply of $j_{6}$ counselor in the detail design phase \\
$C D D$ & Total cost of detail design phase \\
\hline
\end{tabular}

\subsection{Mathematical Modelling}

Since the purpose of this article is the simultaneous optimization of two objectives (time and cost of the project), to implement a model that is capable of satisfying such constraints, a mathematical model with a description of the objective functions and constraints needs to be brought in. There are various methods for a variety of these problems that have a higher priority due to the nature of the problem, the decision variables, and the objective function to solve a particular problem. A particular issue of problems is goal programming or the ideal multi-objective function of planning. In these kinds of problems, we probably deal with the multi-incompatible objective function as well as different measurement units. Each of the $f_{i}$ functions is converted to an $b_{i}$ ideal. Ideals can have different states such as $f i \leq b_{i}$ ' $f_{i}=b_{i}$, or $f_{i} \geq b_{i}$ such that in any state the addition of the r variable can lead to the division minimization of ideals and these types of ideal kinds are presented in Table 5.

Table 5

Different types of ideal kinds

\begin{tabular}{ccc}
\hline Ideal kind & standard form of GP & New objective function for minimization \\
\hline$f_{i}=b_{i}$ & $f_{i}+s_{i}^{+}-s_{i}^{-}=b_{i}$ & $s_{i}^{+}+s_{i}^{-}$ \\
$f_{i} \leq b_{i}$ & $f_{i}+s_{i}^{+}-s_{i}^{-}=b_{i}$ & $s_{i}^{-}$ \\
$f_{i} \geq b_{i}$ & $f_{i}+s_{i}^{+}-s_{i}^{-}=b_{i}$ & $s_{i}^{+}$ \\
\hline
\end{tabular}

In total, the objective function can be defined as the weighted sum of ideals' deviation, which, for the correction of the different unit's problem, can be defined as a ratio of the related ideal amount. Attentive to problem's nature, the decision optimization for one or many projects of the two-objective function with different measurement units and the popularity of the definition of favourable amount, such as cost and time of project implementation and timely implementation in the project management literature, are used in the goal programming method to solve the proposed model.

\subsubsection{Proposed model}

\subsubsection{Objective functions and constraints}

As mentioned previously, before start of project, there should first be one main contractor, then an executor, and finally, certain alternatives for project implementation that the main contractor selects from Eq. (1). This constraint implies that only one main contractor for the project will be selected.

$$
\sum_{i_{1}=1}^{n_{1}} M C_{i_{1}}=1, \quad \forall i_{1}: M C_{i_{1}}=0 \text { or } 1
$$

Eq. (2) is used for the limitation of the project executor's selection to just one executor and the Eq. (3) implies that the executor can select its related contractor be selected in the previous stage. 


$$
\begin{aligned}
& \sum_{i_{1}=1}^{n_{1}} \sum_{i_{2}=1}^{n_{2}} E X_{i_{1}, i_{2}}=1, \forall i_{1}, i_{2}: E X_{i_{1}, i_{2}}=0 \text { or } 1 \\
& \sum_{i_{2}=1}^{n_{2}} E X_{i_{1}, i_{2}}-M C_{i_{1}}=0, i_{1}=1, \ldots, n_{1}
\end{aligned}
$$

The following constraints represent the sequence needed to choose an alternative and make choices on the related alternatives for the main contractor and the selected executor in the previous step.

$$
\begin{aligned}
& \sum_{i_{1}=1}^{n_{1}} \sum_{i_{2}=1}^{n_{2}} \sum_{i_{3}=1}^{n_{3}} A_{i_{1}, i_{2}, i_{3}}=1, \forall i_{1}, i_{2}, i_{3}: A_{i_{1}, i_{2}, i_{3}}=0 \text { or } 1 \\
& \sum_{i_{2}=1}^{n_{2}} \sum_{i_{3}=1}^{n_{3}} A_{i_{1}, i_{2}, i_{3}}-M C_{i_{1}}=0, i_{1}=1, \ldots, n_{1} \\
& \sum_{i_{3}=1}^{n_{3}} A_{i_{1}, i_{2}, i_{3}}-E X_{i_{1}, i_{2}}=0, \forall i_{1}, i_{2}
\end{aligned}
$$

\subsubsection{Conceptual design phase}

After the alternative has been selected, the conceptual design stage starts. This phase consists of several activities that are below the constraint means, i.e., each activity must supply a fraction of their supply needs through the existing suppliers to have their operational requirements entirely met. The sum of these fractions should be equal to one. Eq. (7) also states that the supply fraction for each activity of each supplier has to be a number between zero and one.

$$
\begin{aligned}
& \sum_{i_{1}=1}^{n_{1}} \sum_{i_{2}=1}^{n_{2}} \sum_{i_{3}=1}^{n_{3}} \sum_{j_{1}=1}^{m_{1}} \operatorname{supe}_{i_{1}, i_{2}, i_{3}, i_{4}, j_{1}}=1, \quad i_{4}=1, \ldots, n_{4} \\
& \forall i_{1}, i_{2}, i_{3}, i_{4}, j_{1}: 0 \leq \operatorname{supe}_{i_{1}, i_{2}, i_{3}, i_{4}, j_{1}} \leq 1
\end{aligned}
$$

The following restriction indicates that the supply amount dedicated to each of the suppliers is equal to a fraction of the activity needed, which, while being prepared by the suppliers, must be less than the capacity of the suppliers.

$$
\text { Demand }_{i_{1}, i_{2}, i_{3}, i_{4}} \times \text { supe }_{i_{1}, i_{2}, i_{3}, i_{4}, j_{1}} \leq \text { CapSupe } i_{1}, i_{2}, i_{3}, i_{4}, j_{1}, \quad \forall i_{1}, i_{2}, i_{3}, i_{4}, j_{1}
$$

The following restriction is indicated in the start time of the first activity in the contractor's selection of all possible scenarios, executors, and alternatives, which will be zero because this is the first activity of the first stage of the project.

$$
\text { tes }_{i_{1}, i_{2}, i_{3}, 1}=0, \quad \forall i_{1}, i_{2}, i_{3}
$$

The restrictions following this stage indicate that the end time of each activity is equal to the time duration of the activity implementation by adding the activity starting time:

$$
t e f_{i_{1}, i_{2}, i_{3}, i_{4}} \geq t e s_{i_{1}, i_{2}, i_{3}, i_{4}}+t e_{i_{1}, i_{2}, i_{3}, i_{4}}, \quad \forall i_{1}, i_{2}, i_{3}, i_{4}
$$


The constraints mentioned below indicate the start of any activity specified with regard to the end of its preferred activity and the time duration between the end of the preferred activity and the start of the dependent activity.

$$
\text { tef } f_{i_{1}, i_{2}, i_{3}, i_{4}}+\operatorname{lag}_{i_{1}, i_{2}, i_{3}, i_{4}, i_{4}^{\prime}} \leq \operatorname{tes}_{i_{1}, i_{2}, i_{3}, i_{4}^{\prime}}, \quad \forall i_{1}, i_{2}, i_{3}, i_{4}, i_{4}^{\prime}
$$

Through consideration, any supplier can reach a fraction of the supply. The time duration of implementation will, therefore, also be a fraction of the project implementation that will be entirely implemented by the suppliers. The time duration of the project implementation is the maximum involved time of the suppliers in this project.

$$
t e_{i_{1}, i_{2}, i_{3}, i_{4}}=\max _{j_{1}}\left(\operatorname{tesup}_{i_{1}, i_{2}, i_{3}, i_{4}, j_{1}} \times \operatorname{supe}_{i_{1}, i_{2}, i_{3}, i_{4}, j_{1}}\right), \quad \forall i_{1}, i_{2}, i_{3}, i_{4}
$$

Time running out of a stage to reach another stage, such as in the conceptual design stage, equal the maximum time of completion of the activities that are calculated with the constraints mentioned below.

$$
T E D=\max _{i_{1}, i_{2}, i_{3}, i_{4}}\left(t e f_{i_{1}, i_{2}, i_{3}, i_{4}}\right)
$$

The same constraints, Eqs.(7-8), are under limitations, but the consulters and the supervisors will have to typically monitor the implementation of the activities.

$$
\begin{aligned}
& \sum_{i_{1}=1}^{n_{1}} \sum_{i_{2}=1}^{n_{2}} \sum_{i_{3}=1}^{n_{3}} \sum_{j_{2}=1}^{m_{2}} \text { conse }_{i_{1}, i_{2}, i_{3}, i_{4}, j_{2}}=1, \quad i_{4}=1, \ldots, n_{4} \\
& \forall i_{1}, i_{3}, i_{4}, j_{2}: 0 \leq \text { conse }_{i_{1}, i_{2}, i_{3}, i_{4}, j_{1}} \leq 1 \\
& \text { Demand }_{i_{1}, i_{2}, i_{3}, i_{4}} \times \text { conse }_{i_{1}, i_{2}, i_{3}, i_{4}, j_{2}} \leq \text { CapConse } i_{1}, i_{2}, i_{3}, i_{4}, j_{2}, \quad \forall i_{1}, i_{2}, i_{3}, i_{4}, j_{2}
\end{aligned}
$$

The following constraints calculate the implementing cost of the conceptual design stage.

$$
\sum_{i_{4}=1}^{n_{4}}\left(\sum_{i_{1}=1}^{n_{1}} \sum_{i_{2}=1}^{n_{2}} \sum_{i_{3}=1}^{n_{3}} \sum_{j_{1}=1}^{m_{1}} \operatorname{csupe}_{i_{1}, i_{2}, i_{3}, i_{4}, j_{1}} \times \operatorname{supe}_{i_{1}, i_{2}, i_{3}, i_{4}, j_{1}}+\sum_{i_{1}=1}^{n_{1}} \sum_{i_{2}=1}^{n_{2}} \sum_{i_{3}=1}^{n_{3}} \sum_{j_{2}=1}^{m_{2}} \operatorname{cconse}_{i_{1}, i_{2}, i_{3}, i_{4}, j_{2}} \times \operatorname{conse}_{i_{1}, i_{2}, i_{3}, i_{4}, j_{2}}\right)=C E D
$$

\subsubsection{Preliminary design phase}

For the preliminary design phase as well as the constraints with the same logic regarding the conceptual design phase to allocate a fraction of each activity to the suppliers include:

$$
\begin{aligned}
& \sum_{i_{1}=1}^{n_{1}} \sum_{i_{2}=1}^{n_{2}} \sum_{i_{3}=1}^{n_{3}} \sum_{j_{3}=1}^{m_{3}} \operatorname{supc}_{i_{1}, i_{2}, i_{3}, i_{5}, j_{3}}=1, i_{5}=1, \ldots, n_{5} \\
& \forall i_{1}, i_{2}, i_{3}, i_{5}, j_{3}: 0 \leq \operatorname{supc}_{i_{1}, i_{2}, i_{3}, i_{5}, j_{3}} \leq 1 \\
& \operatorname{Demand}_{i_{1}, i_{2}, i_{3}, i_{5}} \times \operatorname{supc}_{i_{1}, i_{2}, i_{3}, i_{5}, j_{3}} \leq \operatorname{CapSupc}_{i_{1}, i_{2}, i_{3}, i_{5}, j_{3}}, \quad \forall i_{1}, i_{2}, i_{3}, i_{5}, j_{3}
\end{aligned}
$$

There are constraints on the implementation time of the activities in the preliminary design phase as well as the limitations of the conceptual design; the only difference is that the related constraint at the start time of the first activity in this phase Eq. (20) is not equal to zero, unlike the related constraint in the conceptual design stage - it is equal to complementation time of the conceptual design phase. 


$$
\begin{aligned}
& 416 \\
& t c s_{i_{1}, i_{2}, i_{3}, 1}=T E D, \forall i_{1}, i_{2}, i_{3} \\
& t c f_{i_{1}, i_{2}, i_{3}, i_{5}} \geq t c s_{i_{1}, i_{2}, i_{3}, i_{5}}+t c_{i_{1}, i_{2}, i_{3}, i_{5}}, \forall i_{1}, i_{2}, i_{3}, i_{5} \\
& t c s_{i_{1}, i_{2}, i_{3}, i_{5}}+\operatorname{lag}_{i_{1}, i_{2}, i_{3}, i_{5}, i_{5}} \leq t c s_{i_{1}, i_{2}, i_{3}, i_{5}^{\prime}}, \quad \forall i_{1}, i_{2}, i_{3}, i_{5}, i_{5}^{\prime} \\
& t c_{i_{1}, i_{2}, i_{3}, i_{5}}=\max _{j_{3}}\left(t c s u p_{i_{1}, i_{2}, i_{3}, i_{5}, j_{3}} \times \operatorname{supe}_{i_{1}, i_{2}, i_{3}, i_{5}, i_{3}}\right), \quad \forall i_{1}, i_{2}, i_{3}, i_{5} \\
& T C D=\max _{i_{1}, i_{2}, i_{3}, i_{5}}\left(t c f_{i_{1}, i_{2}, i_{3}, i_{5}}\right)
\end{aligned}
$$

The constraint to allocate a fraction of each activity in order to monitor the implementation typically includes:

$$
\begin{aligned}
& \sum_{i_{1}=1}^{n_{1}} \sum_{i_{2}=1}^{n_{2}} \sum_{i_{3}=1}^{n_{3}} \sum_{j_{4}=1}^{m_{4}} \operatorname{consc}_{i_{1}, i_{2}, i_{3}, i_{5}, j_{4}}=1 i_{5}=1, \ldots, n_{5} \\
& \forall i_{1}, i_{2}, i_{3}, i_{5}, j_{4}: 0 \leq \operatorname{consc}_{i_{1}, i_{2}, i_{3}, i_{5}, j_{4}} \leq 1 \\
& \operatorname{Demand}_{i_{1}, i_{2}, i_{3}, i_{5}} \times \operatorname{consc}_{i_{1}, i_{2}, i_{3}, i_{5}, j_{4}} \leq \operatorname{CapConsc}_{i_{1}, i_{2}, i_{3}, i_{5}, j_{4}}, \forall i_{1}, i_{2}, i_{3}, i_{5}, j_{4}
\end{aligned}
$$

Costs related to the implementation, and the monitoring of the preliminary design stage is calculated as well as the following equation.

$$
\begin{aligned}
& \sum_{i_{5}=1}^{n_{5}}\left(\sum_{i_{1}=1}^{n_{1}} \sum_{i_{2}=1}^{n_{2}} \sum_{i_{3}=1}^{n_{3}} \sum_{j_{3}=1}^{m_{3}} \operatorname{csupc}_{i_{1}, i_{2}, i_{3}, i_{5}, j_{3}} \times \operatorname{supc}_{i_{1}, i_{2}, i_{3}, i_{5}, j_{3}}+\right. \\
& \left.\sum_{i_{1}=1}^{n_{1}} \sum_{i_{2}=1}^{n_{2}} \sum_{i_{3}=1}^{n_{3}} \sum_{j_{4}=1}^{m_{4}} \operatorname{cconsc}_{i_{1}, i_{2}, i_{3}, i_{4}, i_{5}, j_{4}} \times \operatorname{consc}_{i_{1}, i_{2}, i_{3}, i_{4}, i_{5}, j_{4}}\right)=\operatorname{CCD}
\end{aligned}
$$

\subsubsection{Detail design phase}

For the detail design and the constraint with the same logic presented in the previous steps, to allocate a fraction of each activity to suppliers we have

$$
\begin{gathered}
\sum_{i_{1}=1}^{n_{1}} \sum_{i_{2}=1}^{n_{2}} \sum_{i_{3}=1}^{n_{3}} \sum_{j_{5}=1}^{m_{5}} \operatorname{supd}_{i_{1}, i_{2}, i_{3}, i_{6}, j_{5}}=1, \quad i_{6}=1, \ldots, n_{6} \\
\forall i_{1}, i_{2}, i_{3}, i_{6}, j_{5}: 0 \leq \operatorname{supd}_{i_{1}, i_{2}, i_{3}, i_{6}, j_{5}} \leq 1 \\
\operatorname{Demand}_{i_{1}, i_{2}, i_{3}, i_{6}} \times \operatorname{supd}_{i_{1}, i_{2}, i_{3}, i_{6}, j_{5}} \leq \operatorname{CapSupd}_{i_{1}, i_{2}, i_{3}, i_{6}, j_{5}}
\end{gathered}
$$

There are constraints on the implementation time of the activities of the detail design phase as well as the limitations of the previous stages. In constraints related to the start time of the first activity of this step, or Eq. (31), the start time of the first activities of this stage is equal to complementation time of the preliminary design phase.

$$
\begin{aligned}
& t d s_{i_{1}, i_{2}, i_{3}, 1}=T C D, \forall i_{1}, i_{2}, i_{3} \\
& t d s_{i_{1}, i_{2}, i_{3}, 1}=T C D, \forall i_{1}, i_{2}, i_{3} \\
& t d s_{i_{1}, i_{2}, i_{3}, i_{6}}+\operatorname{lag}_{i_{1}, i_{2}, i_{3}, i_{6}, i_{6}^{\prime}} \leq t d s_{i_{1}, i_{2}, i_{3}, i_{6}^{\prime}}, \quad \forall i_{1}, i_{2}, i_{3}, i_{6}, i_{6}^{\prime} \\
& t d_{i_{1}, i_{2}, i_{3}, i_{6}}=\max _{j_{5}}\left(t d \sup _{i_{1}, i_{2}, i_{3}, i_{6}, j_{5}} \times \operatorname{supd}_{i_{1}, i_{2}, i_{3}, i_{6}, i_{5}}\right), \quad \forall i_{1}, i_{2}, i_{3}, i_{6} \\
& T D D=\max _{i_{1}, i_{2}, i_{3}, i_{6}}\left(t d f_{i_{1}, i_{2}, i_{3}, i_{6}}\right)
\end{aligned}
$$

The constraints to allocate a fraction of each activity in order to monitor the implementation for consorters typically are as follows: 


$$
\begin{aligned}
& \sum_{i_{1}=1}^{n_{1}} \sum_{i_{2}=1}^{n_{2}} \sum_{i_{3}=1}^{n_{3}} \sum_{j_{4}=1}^{m_{4}} \operatorname{consd}_{i_{1}, i_{2}, i_{3}, i_{6}, j_{6}}=1, \quad i_{6}=1, \ldots, n_{6} \\
& \forall i_{1}, i_{2}, i_{3}, i_{6}, j_{6}: 0 \leq \operatorname{consd}_{i_{1}, i_{2}, i_{3}, i_{6}, j_{6}} \leq 1 \\
& \text { Demand }_{i_{1}, i_{2}, i_{3}, i_{6}} \times \operatorname{consd}_{i_{1}, i_{2}, i_{3}, i_{6}, j_{6}} \leq \text { CapConsd }_{i_{1}, i_{2}, i_{3}, i_{6}, j_{6}}, \quad \forall i_{1}, i_{2}, i_{3}, i_{6}, j_{6}
\end{aligned}
$$

Costs related to the implementation and monitoring of the detail design stage (which is calculated) is as follows,

$$
\sum_{i_{6}=1}^{n_{6}}\left(\sum_{i_{1}=1}^{n_{1}} \sum_{i_{2}=1}^{n_{2}} \sum_{i_{3}=1}^{n_{3}} \sum_{j_{5}=1}^{m_{5}} \operatorname{csupd}_{i_{1}, i_{2}, i_{3}, i_{6}, j_{5}} \times \operatorname{supd}_{i_{1}, i_{2}, i_{3}, i_{6}, j_{5}}+\sum_{i_{1}=1}^{n_{1}} \sum_{i_{2}=1}^{n_{2}} \sum_{i_{3}=1}^{n_{3}} \sum_{j_{6}=1}^{m_{6}} \operatorname{cconsd}_{i_{1}, i_{2}, i_{3}, i_{6}, j_{6}} \times \operatorname{consd}_{i_{1}, i_{2}, i_{3}, i_{6}, j_{6}}\right)=C D D
$$

To define the objective function, the following constraints are present:

$$
\text { TotalCost }=C E D+C C D+C D D
$$

TotalTime $=T P$

Given the presence of the two objectives, for any purpose, an ideal amount is considered in the following limits:

$$
\begin{aligned}
& \text { TotalCostCED }+ \text { SCost }^{+}-S \text { Cost }^{-}=\text {CostGoal } \\
& \text { TotalTime }+ \text { STime } \\
& \text { TSTime }^{-}=\text {TimeGoal }
\end{aligned}
$$

Thus the ultimate objective function is:

$$
\min z=S T i m e^{-}+S \operatorname{Cost}^{-}
$$

\section{Implementation of the model}

\subsection{Solution procedure}

The supply chain of research projects of this paper has been considered with six level structures, which includes an employer, many contractors, many executors, many suppliers, many consulters, a supervisor, and a customer (the end user). In the beginning of the project there is one employer who should select the best option between many contractors and many executors. Proper executers must examine the alternatives and select the most appropriate option. Then, the selected executors should implement the project life cycle sequentially. The best suppliers, consultants, and supervisors should be selected, and the feasibility and the conceptual design, the preliminary design, and the detailed design stage are involved in the project.

\subsection{Implementation}

The proposed model is implemented in the GAMS software and was tested by a Research project organization using a real data model.

\section{Table 6}

Description of the case study

\begin{tabular}{llll}
\hline Main contractor & & First alternative & Second alternative \\
\hline First contractor & First executor & 1 & 1 \\
First contractor & Second executor & 1 & 1000000 \\
Second contractor & First executor & 1 & 1 \\
Second contractor & Second executor & 1 & 1000000 \\
\hline
\end{tabular}


Given that the two main contractors and the second executor of both the contractors have only one implementation alternative with respect to a cost element for the selection of the second alternative by the executors, choosing this alternative is impossible by the GAMS software as it does not actually exist (Table 6). The first index shows the main contractor in the input, the second index shows the executor, and the third index displays the alternative. In the solved case study, all the supply requirements and a monitoring of all activities of all the stages are considered in Table 7.

Table 7

Description of the case study

\begin{tabular}{lllcc}
\hline Main contractor & & & First activity & Second activity \\
\hline First contractor & First executor & First alternative & 20 & 15 \\
First contractor & First executor & Second alternative & 15 & 15 \\
First contractor & Second executor & First alternative & 20 & 20 \\
First contractor & Second executor & Second alternative & 10 & 15 \\
Second contractor & First executor & First alternative & 18 & 20 \\
Second contractor & First executor & Second alternative & 20 & 14 \\
Second contractor & Second executor & First alternative & 15 & 20 \\
Second contractor & Second executor & Second alternative & 12 & 30 \\
\hline
\end{tabular}

In this research, three suppliers are considered who defined the capacity of each supplier or consulter for the implementation monitoring in each stage of the project life cycle to which the supplier's capacity is brought for the supply of the conceptual design activity in Table 8. To calculate the time consumed in performing the conceptual design activity, the implemented time is considered when the complete transfer of any activity to any supplier takes place, in which case the negative numbers indicate a lack of suppliers for the activities. In addition, in a case study example, for the activities of conceptual design, it is considered the cost of any activity if it is completely supplied by any supplier and if all the possible combinations for contractors, executors, and alternatives are selected. Table 8 contains the time and cost of each activity as a complete supply from any suppliers in the event of selection of all the possible combinations for contractors, executors, and alternatives.

Table 8

Related data to suppliers in conceptual design stage

\begin{tabular}{|c|c|c|c|c|c|c|c|c|c|c|c|c|}
\hline \multirow{2}{*}{$\begin{array}{l}\text { Main } \\
\text { contractor }\end{array}$} & & & & \multicolumn{3}{|c|}{ First supplier } & \multicolumn{3}{|c|}{ Second supplier } & \multicolumn{3}{|c|}{ Third supplier } \\
\hline & & & & Capacity & Time & cost & Capacity & Time & cost & Capacity & Time & cost \\
\hline $\begin{array}{l}\text { First } \\
\text { contractor }\end{array}$ & $\begin{array}{l}\text { First } \\
\text { executor }\end{array}$ & $\begin{array}{l}\text { First } \\
\text { alternative }\end{array}$ & $\begin{array}{l}\text { First } \\
\text { activity }\end{array}$ & 25 & 20 & 1000 & 10 & 20 & 1000 & 25 & 18 & 1400 \\
\hline $\begin{array}{l}\text { First } \\
\text { contractor }\end{array}$ & $\begin{array}{l}\text { First } \\
\text { executor }\end{array}$ & $\begin{array}{l}\text { First } \\
\text { alternative }\end{array}$ & $\begin{array}{l}\text { Second } \\
\text { activity }\end{array}$ & 20 & 15 & 2000 & 20 & 15 & 2000 & 20 & 10 & 500 \\
\hline $\begin{array}{l}\text { First } \\
\text { contractor }\end{array}$ & $\begin{array}{l}\text { First } \\
\text { executor }\end{array}$ & $\begin{array}{l}\text { Second } \\
\text { alternative }\end{array}$ & $\begin{array}{l}\text { First } \\
\text { activity }\end{array}$ & 15 & 20 & 1500 & 25 & 20 & 1400 & 10 & 20 & 3000 \\
\hline $\begin{array}{l}\text { First } \\
\text { contractor }\end{array}$ & $\begin{array}{l}\text { First } \\
\text { executor }\end{array}$ & $\begin{array}{l}\text { Second } \\
\text { alternative }\end{array}$ & $\begin{array}{l}\text { Second } \\
\text { activity }\end{array}$ & 25 & 12 & 1500 & 30 & 10 & 2000 & 25 & 12 & 2500 \\
\hline $\begin{array}{l}\text { First } \\
\text { contractor }\end{array}$ & $\begin{array}{l}\text { Second } \\
\text { executor }\end{array}$ & $\begin{array}{l}\text { First } \\
\text { alternative }\end{array}$ & $\begin{array}{l}\text { First } \\
\text { activity }\end{array}$ & 50 & 15 & 1000 & 20 & 15 & 2000 & 15 & 15 & 1000 \\
\hline $\begin{array}{l}\text { First } \\
\text { contractor }\end{array}$ & $\begin{array}{l}\text { Second } \\
\text { executor }\end{array}$ & $\begin{array}{l}\text { First } \\
\text { alternative }\end{array}$ & $\begin{array}{l}\text { Second } \\
\text { activity }\end{array}$ & 20 & 10 & 2000 & 10 & 14 & 1000 & 20 & 14 & 2000 \\
\hline $\begin{array}{l}\text { First } \\
\text { contractor }\end{array}$ & $\begin{array}{l}\text { Second } \\
\text { executor }\end{array}$ & $\begin{array}{l}\text { Second } \\
\text { alternative }\end{array}$ & $\begin{array}{l}\text { First } \\
\text { activity }\end{array}$ & 10 & 10 & 1000 & 15 & 20 & 500 & 0 & 15 & 1200 \\
\hline $\begin{array}{l}\text { First } \\
\text { contractor }\end{array}$ & $\begin{array}{l}\text { Second } \\
\text { executor }\end{array}$ & $\begin{array}{l}\text { Second } \\
\text { alternative }\end{array}$ & $\begin{array}{l}\text { Second } \\
\text { activity }\end{array}$ & 5 & 10 & -1 & 0 & 15 & -1 & 10 & -1 & 2000 \\
\hline $\begin{array}{l}\text { Second } \\
\text { contractor }\end{array}$ & $\begin{array}{l}\text { First } \\
\text { executor }\end{array}$ & $\begin{array}{l}\text { First } \\
\text { alternative }\end{array}$ & $\begin{array}{l}\text { First } \\
\text { activity }\end{array}$ & 15 & 12 & 1500 & 20 & 20 & 1000 & 15 & 20 & 1500 \\
\hline $\begin{array}{l}\text { Second } \\
\text { contractor }\end{array}$ & $\begin{array}{l}\text { First } \\
\text { executor }\end{array}$ & $\begin{array}{l}\text { First } \\
\text { alternative }\end{array}$ & $\begin{array}{l}\text { Second } \\
\text { activity }\end{array}$ & 10 & 20 & -1 & 15 & 15 & 1000 & 20 & 10 & 1000 \\
\hline $\begin{array}{l}\text { Second } \\
\text { contractor }\end{array}$ & $\begin{array}{l}\text { First } \\
\text { executor }\end{array}$ & $\begin{array}{l}\text { Second } \\
\text { alternative }\end{array}$ & $\begin{array}{l}\text { First } \\
\text { activity }\end{array}$ & 15 & 15 & 1500 & 15 & 10 & 2000 & 20 & 10 & 1800 \\
\hline $\begin{array}{l}\text { Second } \\
\text { contractor }\end{array}$ & $\begin{array}{l}\text { First } \\
\text { executor }\end{array}$ & $\begin{array}{l}\text { Second } \\
\text { alternative }\end{array}$ & $\begin{array}{l}\text { Second } \\
\text { activity }\end{array}$ & 20 & 20 & 1000 & 20 & 15 & 1000 & 15 & 10 & 2000 \\
\hline $\begin{array}{l}\text { Second } \\
\text { contractor }\end{array}$ & $\begin{array}{l}\text { Second } \\
\text { executor }\end{array}$ & $\begin{array}{l}\text { First } \\
\text { alternative }\end{array}$ & $\begin{array}{l}\text { First } \\
\text { activity }\end{array}$ & 12 & 15 & 1200 & 20 & 10 & 2000 & 10 & 20 & 1000 \\
\hline $\begin{array}{l}\text { Second } \\
\text { contractor }\end{array}$ & $\begin{array}{l}\text { Second } \\
\text { executor }\end{array}$ & $\begin{array}{l}\text { First } \\
\text { alternative }\end{array}$ & $\begin{array}{l}\text { Second } \\
\text { activity }\end{array}$ & 30 & 20 & 1500 & 10 & 20 & 2000 & 20 & 20 & 1500 \\
\hline $\begin{array}{l}\text { Second } \\
\text { contractor }\end{array}$ & $\begin{array}{l}\text { Second } \\
\text { executor }\end{array}$ & $\begin{array}{l}\text { Second } \\
\text { alternative }\end{array}$ & $\begin{array}{l}\text { First } \\
\text { activity }\end{array}$ & 15 & 15 & -1 & 15 & 18 & -1 & 15 & 15 & 1000 \\
\hline $\begin{array}{l}\text { Second } \\
\text { contractor }\end{array}$ & $\begin{array}{l}\text { Second } \\
\text { executor }\end{array}$ & $\begin{array}{l}\text { Second } \\
\text { alternative }\end{array}$ & $\begin{array}{l}\text { Second } \\
\text { activity }\end{array}$ & 20 & 10 & 1000 & 20 & -1 & 1000 & 0 & -1 & 1000 \\
\hline
\end{tabular}


In this research, we consider two consulters for any phase, which are indicated in Table 9 that exhibits the consulter capacity for the monitoring of conceptual design activity, implementation time and cost. With regard to the two activities in all the life cycles for each phase and the two suppliers and the two consulters/supervisors for each of them, the data from any of them is presented in the indication suppliers' capacity and the other stage supervisor. All the concerned entries are listed in the sheets with the same name as the related parameter to their specific stage in the Excel file. The monitor terms similar to the implementation of the other steps' activities is used to enter all of the related table numbers.

To express the time interval between the activities, the in-form of the FS for Lag parameters is used. Table 10 shows the values for the activities at all the stages of the conceptual design phase, which is used in all the other stages due to the same conditions and the same inputs. The important point is that the relationship between the two activities is the only positive value between the two processes; great negative values indicate a lack of alternatives for the conceptual design stage.

\section{Table 9}

Related data to consulter/supervisor in conceptual design stage

\begin{tabular}{|c|c|c|c|c|c|c|c|c|c|}
\hline \multirow[t]{2}{*}{ Main contractor } & & & & \multicolumn{3}{|c|}{ First consulter/ supervisor } & \multicolumn{3}{|c|}{ Second consulter/supervisor } \\
\hline & & & & Capacity & Time & cost & Capacity & Time & cost \\
\hline First contractor & First executor & First alternative & First activity & 25 & 25 & 2500 & 20 & 15 & 1000 \\
\hline First contractor & First executor & First alternative & Second activity & 20 & 20 & 1000 & 20 & 10 & 2000 \\
\hline First contractor & First executor & $\begin{array}{l}\text { Second } \\
\text { alternative }\end{array}$ & First activity & 20 & 5 & 500 & 15 & 15 & 1500 \\
\hline First contractor & First executor & $\begin{array}{l}\text { Second } \\
\text { alternative }\end{array}$ & Second activity & 20 & 20 & 1200 & 12 & 12 & 1200 \\
\hline First contractor & $\begin{array}{l}\text { Second } \\
\text { executor }\end{array}$ & First alternative & First activity & 15 & 4 & 1500 & 45 & 18 & 700 \\
\hline First contractor & $\begin{array}{l}\text { Second } \\
\text { executor }\end{array}$ & First alternative & Second activity & 30 & 20 & 5000 & 20 & 15 & 1000 \\
\hline First contractor & $\begin{array}{l}\text { Second } \\
\text { executor }\end{array}$ & $\begin{array}{l}\text { Second } \\
\text { alternative }\end{array}$ & First activity & 0 & 10 & -1 & 0 & 10 & 2000 \\
\hline First contractor & $\begin{array}{l}\text { Second } \\
\text { executor }\end{array}$ & $\begin{array}{c}\text { Second } \\
\text { alternative }\end{array}$ & Second activity & 0 & -1 & -1 & 0 & -1 & 1000 \\
\hline Second contractor & First executor & First alternative & First activity & 20 & 12 & 2000 & 20 & 10 & 2000 \\
\hline Second contractor & First executor & First alternative & Second activity & 15 & 18 & 3000 & 25 & 15 & 1500 \\
\hline Second contractor & First executor & $\begin{array}{c}\text { Second } \\
\text { alternative }\end{array}$ & First activity & 20 & 20 & 2000 & 30 & 20 & 2000 \\
\hline Second contractor & First executor & $\begin{array}{c}\text { Second } \\
\text { alternative }\end{array}$ & Second activity & 15 & 15 & 1000 & 15 & 25 & 1000 \\
\hline Second contractor & $\begin{array}{l}\text { Second } \\
\text { executor }\end{array}$ & First alternative & First activity & 10 & 20 & 1500 & 20 & 20 & 2000 \\
\hline Second contractor & $\begin{array}{l}\text { Second } \\
\text { executor }\end{array}$ & First alternative & Second activity & 20 & 10 & 2000 & 25 & 10 & 1500 \\
\hline Second contractor & $\begin{array}{l}\text { Second } \\
\text { executor }\end{array}$ & $\begin{array}{c}\text { Second } \\
\text { alternative }\end{array}$ & First activity & 15 & -1 & 1000 & 20 & 10 & 1000 \\
\hline Second contractor & $\begin{array}{l}\text { Second } \\
\text { executor }\end{array}$ & $\begin{array}{l}\text { Second } \\
\text { alternative }\end{array}$ & Second activity & 10 & -1 & -1 & 0 & 10 & 2000 \\
\hline
\end{tabular}

\section{Table 10}

Related data for time interval between activties

\begin{tabular}{|c|c|c|c|c|c|}
\hline Main contractor & & & & First activity & Second activity \\
\hline First contractor & First executor & First alternative & First activity & 0 & 20 \\
\hline First contractor & First executor & First alternative & Second activity & -20 & 0 \\
\hline First contractor & First executor & Second alternative & First activity & 0 & 15 \\
\hline First contractor & First executor & Second alternative & Second activity & -15 & 0 \\
\hline First contractor & Second executor & First alternative & First activity & 0 & 10 \\
\hline First contractor & Second executor & First alternative & Second activity & -10 & 0 \\
\hline First contractor & Second executor & Second alternative & First activity & -10000 & -10000 \\
\hline First contractor & Second executor & Second alternative & Second activity & -10000 & -10000 \\
\hline Second contractor & First executor & First alternative & First activity & 0 & 15 \\
\hline Second contractor & First executor & First alternative & Second activity & -15 & 0 \\
\hline Second contractor & First executor & Second alternative & First activity & 0 & 20 \\
\hline Second contractor & First executor & Second alternative & Second activity & -20 & 0 \\
\hline Second contractor & Second executor & First alternative & First activity & 0 & 10 \\
\hline Second contractor & Second executor & First alternative & Second activity & -10 & 0 \\
\hline Second contractor & Second executor & Second alternative & First activity & -10000 & -10000 \\
\hline Second contractor & Second executor & Second alternative & Second activity & -10000 & -10000 \\
\hline
\end{tabular}




\subsection{Solution to the problem}

The results of the code implementation are mentioned in the following entries. GAMS output states that the Main Contractor 1, the first main executor for the Contractor 1, and the first alternative are selected. The combined selection of the suppliers for the conceptual design phase activities' supply is shown as follows:

The results suggest (as previously mentioned) that Contractor 1, Executor 2, and Executive Alternative 2 of Executor 2, of Contractor 1, and for Activity 1 need to be supplied with 5 percent of Supplier 2 and 95 percent of Supplier 3, but the second activity is supplied by all the requirements of Supplier 2, the supplier. Examining the other variables in the same way it was found that:

- All the monitoring of Activity 1 of the conceptual design was assigned to the Consultant 2, and all the supervisors of Activity 2 in that stage were assigned to Consulter 1.

- The cost of the conceptual design stage (CED) is equal to 2000 currency.

- All supply of Activity 1 in the preliminary design stage has been supplied to Supplier 2 and all the supply of Activity 2 has been supplied to Supplier 1.

- All the surveillance of Activity 1 in the preliminary design stage has been transferred to Consultant 1 and all the monitoring of Activity 2 has been supplied to Consultant 2 .

- The cost of the preliminary design stage (CCD) is equal to 1200 currency.

- All the supply of Activity 1 in the detail design stage has been transferred to Supplier 2 and all the supply of Activity 2 has been transferred to Supplier 1.

- All the surveillance of Activity 1 in the detail design stage has been transferred to Consultant 1 and all the monitoring of Activity 2 has been transferred to Consultant 2.

- The cost of the detail design stage (CDD) is equal to 1500 currency.

The related results of the start and the end of each activity are available. The final answer of the model is elliptical in the variable value mentioned below. The values of the ideal for the cost logarithm and the implementation time of the entire project are respectively placed in Table 11.

Table 11

Optimal values of the case study

$\begin{array}{ll}\text { Goal value of cost logarithm } & 1000\end{array}$

$\begin{array}{ll}\text { Goal value of time logarithm } & 178\end{array}$

This project was closed without the use of models in five years (700 days) at a cost of \$2000 million. The main reason for the high cost and time was due to an incorrect choice of the network of suppliers and consultants. The used model was closed within 178 days and costed $\$ 1000$ million.

\subsection{Validation of the model}

There are different tests that can be used in validating the model such as model structural analysis, a sensitivity analysis of the models' parameters, the ultimate point test, and the adequacy test. In this article, we will discuss the structural analysis method for the model to analyze the structure of the objective function, and the constraints and the existence of potential inconsistencies, which have been identified and have been resolved by experts of operations research modelling. According to the availability of information, the model has been test and examine in available case studies. The proposed model is, therefore, valid with real data from research industries in Iran and it has been confirmed and examined by experts in this field from universities and industries, and has thereby proved its validity and reliability. 


\section{Conclusion and future research directions}

Research project proposals are initiated based on stated customer requirement. This proposal are then selected, executed and developed. One of the important factors that impact on the success of this projects is network design of research organizations. Research managers are continually face with a serve of decisions as to, how to select the main contractors, suppliers, executors, most appropriate projects and alternatives. Due to the inherent complexity and uncertainty, Research Projects are not easily amenable for network design. This study aimed to contribute to PSCM literature by developing a unique multi-objective linear programming model that enables decision makers to simultaneously evaluate cost and time for research projects. By considering the literature review that project management deals with, which includes inherent decision handling with multiple conflicting objectives and uncertain situations over the decision making process in the real life applications, this model has been developed as a multi-objective decision problem with goal programming. With the application of this model, managers and decision-makers of the research cycle can compare extant options in the collaboration network and select the network that does not stop the life cycle in any phase and assures the success of the project.

This study has some limitations with regard to the model and the methodology that can be employed in the future studies to be conducted on the project network literature. Although the mathematical model of the study can alter with the major conflicting objectives and decision making factors in project network problems, the other objectives such as corporative relationships can be added to the model for satisfying the requirements of different real life problems to be solved. In addition, the model can be expanded with addition of some constraints to bring a solution to a specific problem. The other limitation of the model can be attributed the fuzziness dealing with only the unclear objectives. However, in real life situation the Project managers confront with uncertain, imprecise information with regard to cost and time. Therefore, the future studies with fuzzy parameters can be conducted to cope with this type of vagueness, as suggested in the other studies.

\section{References}

Asbjørnslett, B. E. (2003). Project supply chain management: From agile to lean.

Basu, R. (2011). Managing project supply chains. Gower Publishing, Ltd.

Burton, N., \& Lanciault, D. (1999). Creating supply advantage for oil and gas companies with strategic procurement. Oil \& Gas Journal, 97(44), 54-54.

Beamon, B. M. (1998). Supply chain design and analysis:: Models and methods. International Journal of Production Economics, 55(3), 281-294.

Chopra, S., \& Meindl, P. (2007). Supply chain management. Strategy, planning \& operation. Das Summa Summarum Des Management, 265-275.

CRINE (1998). CRINE Network Supply Chain Management Initiative. In CRINE Network Watch London.

Cousins, P. D., \& Spekman, R. (2003). Strategic supply and the management of inter-and intraorganisational relationships. Journal of Purchasing and supply Management, 9(1), 19-29.

Eriksson, P. E. (2015). Partnering in engineering projects: Four dimensions of supply chain integration. Journal of Purchasing and Supply Management, 21(1), 38-50.

Ghassemi, A., Asl-Najafi, J., \& Yaghoubi, S. (2018). A dynamic bi-objective closed-loop supply chain network design considering supplier selection and remanufacturer subcontractors. Uncertain Supply Chain Management, 6(2), 117-134.

Goetschalckx, M., Vidal, C. J., \& Dogan, K. (2002). Modeling and design of global logistics systems: A review of integrated strategic and tactical models and design algorithms. European Journal of Operational Research, 143(1), 1-18.

Harrison, F. L., \& Lock, D. (2004). Advanced project management: a structured approach. Gower Publishing, Ltd.. 
Kerridge, A. E. (1987). Manage materials effectively. Hydrocarbon processing, 66(5), 63.

Lock, D. (Ed.). (1994). Gower handbook of project management. Gower.

Morris, P., \& Pinto, J. K. (Eds.). (2010). The Wiley guide to project technology, supply chain, and procurement management (Vol. 7). John Wiley \& Sons.

Min, S. (2001). Inter-corporate cooperation. Supply Chain Management. Sage Publications, Inc., Thousand Oaks, CA.

Mishra, A., Chandrasekaran, A., \& MacCormack, A. (2015). Collaboration in Multi-Partner R\&D projects: The impact of partnering scale and scope. Journal of Operations Management, 33, 1-14.

Mohamed, S., \& Tucker, S. (1996). Options for applying BPR in the Australian construction industry. International Journal of Project Management, 14(6), 379-385.

Mangan, J., \& Lalwani, C. (2016). Global logistics and supply chain management. John Wiley \& Sons.

Nassimbeni, G. (1998). Network structures and co-ordination mechanisms: a taxonomy. International Journal of Operations \& Production Management, 18(6), 538-554.

Parrod, N., Thierry, C., Fargier, H., \& Cavaille, J. B. (2007). Cooperative subcontracting relationship within a project supply chain: A simulation approach. Simulation Modelling Practice and Theory, 15(2), 137-152.

Schultzel, H. J., \& Unruh, V. P. (1996). Successful partnering: Fundamentals for project owners and contractors. John Wiley \& Sons.

Siniharju, M. (2000). Collaboration in Project Supply Chain. TU-22.451 Seminar in International Project-Oriented Business, Helsinki.

Silver, E. A. (1986). Procurement and Logistics for Large Scale Projects in the Oil and Gas Industry. University of Calgary. Faculty of Management.

Tam, V. W., Shen, L. Y., \& Kong, J. S. (2011). Impacts of multi-layer chain subcontracting on project management performance. International Journal of Project Management, 29(1), 108-116.

Tarziján, J., \& Brahm, F. (2014). Subcontracting in project-based firms: Do you follow the same pattern across your different projects?. International Journal of Project Management, 32(6), 995-1006.

Turner, J. R. (2008). Handbook of project-based management. McGraw-Hill Professional Publishing.

Vollmann, T. E., Cordon, C., \& Raabe, H. (1995). From supply chain management to demand chain management. IMD Perspectives for Managers, (November), 1-4.

Wingate, L. M. (2014). Project management for research and development: guiding innovation for positive $R \& D$ outcomes. CRC Press.

Yeo, K. T., \& Ning, J. H. (2002). Integrating supply chain and critical chain concepts in engineerprocure-construct (EPC) projects. International Journal of Project Management, 20(4), 253-262.

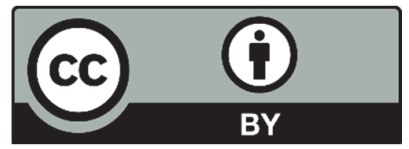

(C) 2018 by the authors; licensee Growing Science, Canada. This is an open access article distributed under the terms and conditions of the Creative Commons Attribution (CC-BY) license (http://creativecommons.org/licenses/by/4.0/). 